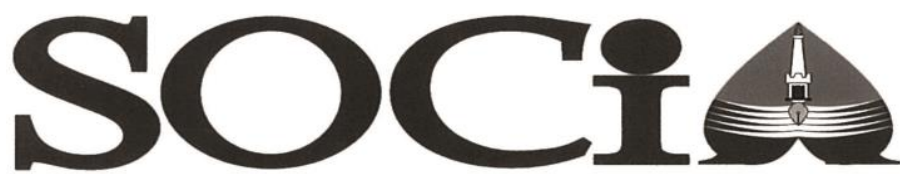

\title{
Peran Elit Politik Lokal dalam Pendidikan Politik Mahasiswa di Kabupaten Lombok Timur
}

\author{
DIDIN SEPTA RAHMADI \\ Program Studi Ilmu Pengetahuan Sosial (IPS) UNY Yogyakarta \\ deanalawi@ymail.com
}

\begin{abstract}
Abstrak
Penelitian ini bertujuan untuk mengetahui peran dari elit politik lokal dalam pendidikan politik, dan pelaksanaan pendidikan politik mahasiswa di lembaga perguruan tinggi di Kabupaten Lombok Timur. Penelitian ini berjenis kualitatif naturalistik yang diadakan dari bulan Maret-Juni. Subjek penelitian ini adalah elit politik lokal. Penarikan informan dilakukan dengan snowball. Teknik pengumpulan data menggunakan observasi, wawancara, dan dokumentasi. Teknik analisis yang digunakan adalah: (1) reduksi data, (2) abstraksi data), dan (3) penarikan kesimpulan. Hasil penelitian di lapangan menunjukkan bahwa: pertama, elit politik lokal hanya malaksanakan pengkaderan untuk konstituennya, yang dalam hal ini mereka sebut pendidikan politik. Pendekatan yang dilakukan untuk mahasiswa adalah melalui bidang kepemudaan yang berfungsi sebagai sayap partai (underbow). Kedua, struktur yayasan dalam politik praktis membawa dampak pada lembaga pendidikan yang di kelola.
\end{abstract}

Kata kunci: Peran, Elit Politik, Pendidikan Politik Mahasiswa.

\section{Abstract}

This research aims to know the role of the local political elites in the political education and the implementation of students political education in East Lombok. This study used naturalistic qualitative research methods conducted from March to June 2013. The subjects of this research were political elites. The research subjects were selected using a snowball sampling technique. Data collection techniques include observations, interviews, and documentations. The data analysis techniques consist of: (1) data reduction, (2) data abstraction, and (3) conclusion. The results show that: first, the local political elites only performed cadre recruitments for their constituents, which in this case is called a political education. The approach directed for students was performed through youth activities that serve as a wing of the party (underbow). Second, the structure of the institution in practical politics has effects on educational institutions being managed.

Keywords: Roles, Local Political Elites, Students Political Education. 


\section{PENDAHULUAN}

Pembangunan karakter (character building) merupakan kepentingan dalam pendidikan. Levenson dalam Massialas (1970, p. 32) mengemukakan: With education there seems to be considerable change in how people define the good citizen.

Urgensi pendidikan memberikan perubahan besar dalam cara orang mendefinisikan warga negara yang baik. Berarti, pendidikan merupakan instrumen dasar manusia untuk membentuk sikap dan prilaku. Sikap dan prilaku nasionalisme terhadap bangsa dan negara sejatinya juga diperoleh dari pendidikan.

Politik merupakan ragam kegiatan di dalam sistem politik (atau negara) yang menyangkut proses menentukan tujuantujuan dari sistem dan melaksanakan tujuan-tujuan tersebut (Petit, 2002, p. 280).

...republic is to be systematically sensitive to the interests and ideas of people-often newly emergent, newly articulated interests and ideas-then there have to be people who are virtuous enough to press appropriate claims; this applies both in the politics of difference and in the politics of common concerns.

Menentukan tujuan-tujuan

tersebut dibutuhkan peran pendidikan yang sebagai pendamping setia bahkan pendidikan dalam proses tersebut mutlak dibutuhkan, dikarenakan dalam perumusan sistem sangat dibutuhkan kemampuan individu terkait keberlangsungan kehidupan berbangsa dan bernegara.

Oleh karena itu, pendidikan politik sangat diperlukan agar dapat membentuk warga negara yang berkepribadian utuh, berketerampilan, sekaligus juga berkesadaran yang tinggi sebagai warga negara yang baik (good citizen). Sebagai bentuk pelaksanaannya adalah pada proses demokrasi yang menentukan hak setiap warga. Pasal 43 Undang-undang Nomor 39 Tahun 1999 tentang HAM menyatakan bahwa: "Setiap warga negara berhak dipilih dan memilih dalam pemilu, berdasarkan hak melalui pemungutan suara yang langsung umum, bebas, dan rahasia, jujur, adil sesuai ketentuan perundang-undangan".

Sadar akan hak dan kewajiban serta memiliki tanggung jawab yang dilandasi oleh nilai-nilai yang berlaku dalam kehidupan berbangsa dan bernegara merupakan proses pencapaian tujuan pendidikan politik. Akan tetapi, tidak dapat dilihat secara langsung namun memerlukan waktu yang cukup lama, hal ini disebabkan karena pendidikan politik berhubungan dengan aspek sikap dan perilaku seseorang. 
Betapa pentingnya pendidikan politik karena terkait dengan aspek sikap dan perilaku. Sehingga dibutuhkan sumbangsih dan peran besar dari generasi muda bangsa tentunya mempengaruhi kehidupan politik bangsa dan negara yang saat ini penuh dengan tantangan. Sebagai generasi penerus bangsa atau angkatan muda yang memiliki pendidikan dan sebagai kaum intelektual sudah sepantasnya memiliki dasar pengetahuan mengenai kehidupan politik bangsanya. Oleh karena itu, generasi penerus bangsa atau angkatan muda yang dapat disebut sebagai mahasiswa dalam kaitannya dengan kehidupan politik sebaiknya memiliki kesadaran politik yang memadai mengenai politik bangsa Indonesia karena mahasiswa merupakan struktur yang unik dalam tatanan masyarakat.

Upaya untuk mengantisipasi kegagalan dari pelaksanaan proses demokratisasi, pendidikan politik mutlak diperlukan. Seperti yang dikemukakan Molo (Lombok Post, 2013, p. 2), pendidikan politik berfungsi sebagai upaya edukatif dan sistematis, maka peran negara melalui lembaga-lembaga pendidikan formal dengan memasukkannya sebagai kurikulum, non formal oleh Lembaga Swadaya Masyarakat (LSM), dan tentunya oleh partai politik. Sisi etis hendaknya dikedepankan sehingga pancapaian tujuan politik itu tidak bertentangan dengan norma yang berlaku di masyarakat dan hukum negara, disinilah filosofi politik dibangun.

Sangat dibutuhkan edukasi berupa cerminan perilaku elit politik lokal dalam pola pikir dan pola tindakan dalam kehidupan sehari-harinya yang mencerminkan nilai-nilai moral dan etika Pancasila yang sejatinya. Tujuan pendidikan politik menurut Kartono (2009, pp. 68-70) salah satunya bagi generasi muda adalah membangun generasi muda Indonesia yang sadar politik, sadar akan hak dan kewajiban politiknya selaku warga negara, disamping sadar akan kehidupan berbangsa dan bernegara berdasarkan pancasila dan UUD 1945 yang harus terus menerus membangun.

$$
\text { Bentuk perwujudannya, }
$$
kesadaran elit politik lokal, diperlukan untuk mengatasi krisis yang penuh integritas. Etika politik diperlukan sebagai pemandu arah dan penentu kualitas pelaksanaan otonomi daerah menuju terwujudnya keadilan sosial yang mensejahterakan seluruh masyarakat karena elit politik memiliki peran sebagai pendamping (advocator) rakyat untuk memberikan peluang tampilnya 
pemimpin-pemimpin politik yang dikhendaki oleh rakyat, dan berusaha menghindari tokoh yang oportunis serta berusaha memberikan kesadaran dan kedaulatan sepenuhnya bagi rakyat untuk memilih dan menentukan figur-figur sebagai wakil yang diandalkan (Pramono (2005, p. 61). Tetapi, politik selalu menjadi ajang uji coba dengan tidak adanya sistem ekonomi yang kokoh yang dapat mensejahterakan rakyat, sistem pertahanan negara yang baik yang bisa menjaga harga diri, dan kedaulatan serta sistem politik yang adil yang mampu menumbuhkan civil society.

Hambatan inilah yang terasa dalam pelaksanaan pendidikan politik di Lombok Timur. Mobilisasi politik yang dilakukan jauh dari sisi kebijaksanaan. Dengan itu, tehnik mobilisasi massa yang dilakukan dengan mengkotak-kotakkan sebuah wilayah dengan pembentukan komunitas dan pendekatan terhadap komunitas yang berdampak akan memuncul sebuah perselisihan atau konflik.

Kondisi politik ini tidak dapat dipungkiri yang membuat generasi penerus bangsa memiliki pandangan sempit mengenai budaya politik. Jadi, politik hanya dipandang sebagai simbol kekuasaan yang berakibat pada timbul sikap apatis terhadap politik. Paparan ini telah terjadi kerapuhan struktural, Sehingga mentalitas mahasiswa di Lombok Timur tidak tumbuh atau terjadi mekanisme kepentingan secara individual terhadap perkembangan mentalitas yang baik. Realitas politik yang berkembang di Indonesia, khususnya di Lombok Timur secara mikro, terutama dalam konteks pelaksanaan otonomi daerah, stabilitas politik dibangun berdasarkan struktur tidak berimbang yakni "struktur dominasi" oleh pusat dalam hubungan pusat daerah, dan cendrung memisahkan realitas politik dari moralitas, sehingga memunculkan sikap yang apatis.

Salah satu penyebab tersendatnya proses reformasi untuk mengwujudkan Indonesia yang demokratis adalah kurang terdidiknya mahasiswa secara politik. Mahasiswa menjadi alat permainan politik tanpa di berikan pemahaman secara politik. Pengetahuan politik tidak cukup dibekali pada kursi perkuliahan. Tetapi, pengetahuan politik mahasiswa dapat dilaksanakan dengan keterlibatan langsung mahasiswa dalam kegiatan ekstrakurikuler dengan melibatkan diri sebagai mahasiswa dalam organisasiorganisasi kemahasiswaan baik itu di internal perguruan tinggi maupun eksternal. 
Keterlaksanaan pendidikan politik mahasiswa diharapkan membawa mahasiswa mampu memliki mentalitas yang kuat, bukan hanya memberikan pemahaman terhadap mahasiswa tentang pendidikan politik yang menjurus pada pembelajaran terhadap orientasi politik praktis. Oleh karena itu, lembaga politik di Lombok Timur tidak menjalankan fungsinya untuk melakukan pendidikan politik mahasiswa. Disebabkan lembaga politik cenderung hanya mengutamakan kepentingan kekuasaan atau kepentingan para elit politik lokal dari pada kepentingan untuk memajukan masyarakat, bangsa dan negara. Hal ini mengakibatkan partisipasi politik yang merupakan salah satu aspek nasionalisme berbangsa dan bernegara mengakibatkan mahasiswa hanya sebagai komuditas politik dengan memunculkan sikap ketidakpercayaan (distrust) terhadap peribadi elit politik lokal bahkan pada sistem politik itu sendiri. Dengan demikian, kajian ini melihat peran aktor politik yang ada di Kabupaten Lombok Timur untuk melaksanakan pendidikan politik yang terfokus pada mahasiswa.

\section{METODE}

Kajian penelitian ini menggunkan metode yang berjenis penelitian kualitatif naturalistik yang bertujuan melihat keaslian fenomena dilapangan dan jauh dari manipulasi. Jenis penelitian naturalistik menurut Nasution (1988, p. 18) adalah gambaran situasi lapangan penelitian bersifat natural atau wajar, sebagaimana adanya, tanpa dimanipulasi, diatur dengan eksperimen atau test.

Sebagai domain dari penelitian ini adalah Kabupaten Lombok Timur NTB. jadwal waktu penelitian dilaksanakan berkisar maksimal 13 bulan yang terhitung dari penyusunal proposal penelitian sampai penulisan hasil penelitian. Lebih rincinya rencana pelaksanaan penelitian untuk proses pencarian data dilakukan sekitar pada bulan Maret 2013 sampai dengan Juli 2013 sampai dengan data yang diperoleh dianggap sudah cukup dalam proses analisis.

Subjek dalam penelitian ini terfokus peran elit politik. Sedangkan objek dari penelitian ini adalah pendidikan politik mahasiswa yang berlokasi di Kabupaten Lombok Timur.

Teknik yang dipakai meliputi observasi, wawancara mendalam, dokumentasi, dan studi pustaka. Penentuan informen dalam penelitian ini dengan memilih model teknik snowball sampling dengan memprtimbangkan informen yang akan dipilih adalah pertama, Pimpinan partai politik yang 
terdiri dari 2 (dua) partai yaitu Partai Golkar dan Partai Keadilan Sejatera (PKS). Pertimbangan dari peniliti memilih 2 partai dikarenakan pada tahun pemilu 2009 berdasarkan data dari Badan Pusat Statistik Kabupaten Lombok Timur (2011, p, 60) memperoleh 49.114 suara yang sah, dan Partai Keadilan Sejahtera 37.966 suara sah. Adapun pertimbangan yang lain untuk memilih ke dua partai tersebut dikarenakan partai tersebut menduduki kursi terbanyak di DPRD Kabupaten Lombok Timur dan kader dari partai politik yang dipilih memiliki jabatan sebagai ketua dan wakil ketua DPRD Kabupaten Lombok Timur.

Kedua, Lembaga eksekutif (pemerintah daerah, jajaran dinas seperti dinas Bankesbangpoldagri). Pertimbangan peneliti memilih pemerintah daerah dikarenakan pemerintah daerah posisi urgen dalam pemberian pendidikan politik, disamping itu juga peneliti mempertimbangakan data berupa kebijakan pendidikan politik yang dilaksanakan lembaga eksekutif.

Ketiga, Lembaga legeslatif (DPRD Kabupaten Lombok Timur). Pertimbangan adalah DPRD sebagai lembaga legeslatif dimana para pimpinan partai politik berada pada lembaga tersebut, sehingga peneliti dalam penulusuran data dapat di dapatkan dari peran lembaga tersebut.

Kempat, Lembaga perguruan tinggi di Kabupaten Lombok Timur terdiri dari 10 Lembaga perguruan tinggi dan tidak ada yang bersatatus sebagai lembaga Perguruan Tinggi Negeri (PTN), keseluruhannya adalah lembaga Perguruan Tinggi Swasta (PTS). Lembaga perguruan tinggi tersebut adalah STKIP (Sekolah Tinggi Keguruan dan Ilmu Pendidikan) Hamzanwadi Selong mewakili yayasan NWDI Pancor Lombok Timur dan STMIK Syeikh Zaenuddin Anjani Lombok Timur mewakili yayasan NWDI Anjani Lombok Timur, dengan pertimbangan dualisme kepemimpinan di tubuh NWDI semenjak tahun 1997. Persaingan ini, memiliki dampak terhadap persaingan politik dari dua yayasan ini sehingga memiliki dampak terhadap mahasiswa didasarkan perbedaan dohtrinasi politik dari pihak yayasan.

Penelitian ini analisis data yang digunakan mengacu pada langkahlangkah yang dipakai oleh Miles dan Huberman (1994, pp. 10-11) yang terdiri atas empat alur kegiatan yang terjadi secara bersamaan yaitu; Pertama, pengumpulan data dilakukan observasi, dan wawancara informan. Data-data tersebut dicatat dalam catatan lapangan 
berbentuk deskriptif tentang apa yang dilihat, apa yang didengar, dan apa yang dialami atau dirasakan oleh subjek penelitian. Catatan deskriptif adalah catatan alami apa adanya dari lapangan tanpa ada komentar atau tafsiran dari peneliti tentang fenomena yang dijumpai. Catatan deskriptif tersebut meliputi transkrip wawancara dan catatan lapangan observasi.

Kedua, reduksi data dilakukan dengan proses pemilihan, pemusatan perhatian pada penyederhanaan, pengabstrakan, dan transformasi data kasar yang muncul dari catatan-catatan tertulis di lapangan. Reduksi data berlangsung secara terus-menerus selama penelitian. Reduksi data merupakan bentuk analisis yang mempertajam, menggolongkan, mengarahkan, membuat yang tidak diperlukan, dan mengorganisasikan data yang diperlukan sesuai fokus permasalahan penelitian.

Reduksi data selama proses pengumpulan data dilakukan melalui proses pemilihan, pemusatan, penyederhanaan, abstraksi, dan transparasi data kasar yang diperoleh dengan menggunakan catatan lapangan. Selanjutnya membuat ringkasan, mengkode, penelusuran tema-tema, membuat gugus-gugus, membuat partisi, dan catatan kecil (memo) pada kejadian ketika dirasa penting. Setelah dilakukan pengkodean data, kemudian data dikelompokkan berdasarkan variabel penelitian sekaligus dilakukan reduksi tahap pertama.

Dimana reduksi tahap ini bertujuan untuk pemilihan data yang diperlukan dalam penelitin sedangkan data yang tidak relevan disisihkan. Selanjutnya untuk memudahkan dalam melakukan penarikan kesimpulan maka dapat dilakukan reduksi tahap kedua, dimana reduksi tahap ini akan menyederhanakan dan mempertajam data penelitian yang disajikan.

Ketiga, penyajian data dilakukan dengan menganalisis atau mengambil tindakan atas pemahaman yang didapat. Penyajian data yang paling sering digunakan dalam penelitian kualitatif adalah berbentuk teks naratif dari catatan lapangan. Penyajian data adalah merupakan tahapan untuk memahami apa yang sedang terjadi dan apa yang harus dilakukan selanjutnya, untuk dianalisis dan diambil tindakan yang dianggap perlu.

Keempat, menarik kesimpulan atau verifikasi dilakukan dengan membuat kesimpulan sementara murni dari katagorisasi data dan selanjutnya mengulangi tahapan-tahapan dari awal 
sebelum menyimpulakan sehingga kesimpulan betul-betul menghasilkan analisis tajam.

\section{HASIL DAN PEMBAHASAN}

Sarana pendidikan di Kabupaten Lombok Timur (2005, p, 190) salah satu jenis sarana yang tersebar keberadaannya di Kabupaten Lombok Timur, memberikan nilai tambahan terhadap masing-masing yang memiliki sarana pendidikan. Keberadaan sarana pendidikan di suatu wilayah dapat menunjukkan suatu perkembangan wilayah dalam penyediaan sarana pelayanan bagi penduduk bahkan penduduk yang dari luar wilayah, sehingga suatu wilayah kecamatan menjadi pusat kegiatan pendidikan di dalam Kabupaten Lombok Timur. Penilaian indeks faktor penyediaan sarana pendidikan, dilakukan terhadap sarana pendidikan pada setiap kecamatan di Kabupaten Lombok Timur yang meliputi sarana pendidikan berupa Taman Kanak-kanak (TK), Sekolah Dasar (SD), Sekolah Menengah Pertama (SMP), Sekolah Menengah Umum (SMU/Sederajat), dan Perguruan Tinggi (PT).

Menurut data dari Badan Pusat Statistik (BPS, 2011, p. 139) Kabupaten Lombok Timur, nilai indeks fungsi pasilitas pendidikan di Kabupaten Lombok Timur tercatat Taman Kanakkanak (TK) atau setara yang berstatus Negeri berjumlah 6 unit, Swasta 290 unit. Sekolah Dasar (SD) atau setara, yang Negeri 658 unit dan Swasta 241 unit. Sekolah Menengah Pertama (SMP) atau setara, Negeri 90 unit, dan Swasta 243 unit. Sekolah Menengah Atas (SMA) atau setara Negeri 33 unit, dan Swasta 196 unit. Sedangkan, untuk Perguruan Tinggi (PT) yang ada di Kabupaten Lombok Timur berjumlah 10 perguruan tinggi dan ini masih di bawah struktur yayasan.

Lombok memiliki corong akademik Universitas Mataram (UNRAM) untuk studi pengetahuan umum dan IAIN Mataram untuk studi agama. Khususnya di Lombok Timur sebagai corong pendidikan tinggi dan besar di Kabupaten ini adalah Sekolah Tinggi Keguruan dan Ilmu Pendidikan (STKIP) Hamzanwadi, dan STMIK Syeikh Zaenuddin. Dua perguruan tinggi ini memiliki corak yang sama, dan dapat dilihat dari sisi pemberian nama akhir dari perguruan tinggi ini adalah orang yang sama. Dua perguruan tinggi ini berada pada naungan organisasi Islam yang besar di Lombok Timur khususnya adalah NW (Nahdlatul Wathan). Akan tetapi, struktur kepemimpinan yayasan berbeda yang disebabkan dualisme kepemimpinan 
antara NW Pancor dan NW Anjani. NW Pancor dibawah pimpinan Hajjah Rauhun Abdul Madjid binti TGKH. Hamzanwadi, dan NW Anjani dibawah pimpinan Hajjah Raehanun Abdul Madjid binti TGKH. Hamzanwadi.

Kedua lembaga pendidikan ini merupakan basis pengkaderan berbagai idiologi yang kebanyakan dalam artian pendidikan agama terutama pengitegrasian pendidikan ke-NW-an. Oleh sebab itu, peneliti memfokuskan mahasiswa yang berada pada perguruan tinggi tersebut dengan pertimbangan untuk melihat proses pelaksanaan pendidikan politik.

Dari hasil observasi peneliti, beberapa kelompok pergerakan mahasiswa yang tersebar luas di Kabupaten Lombok Timur yang bersifat internal seperti KAMMI (Kesatuan Aksi Mahasiswa Islam Indonesia, PMII (Pergerakan Mahasiswa Islam Indonesia, dan HMI (Himpunan Mahasiswa Islam Indonesia) yang bercabang di Kabupaten Lombok Timur. Akan tetapi, keberadaan organisasi tersebut justru menjadi tantangan dari dua kampus dengan alasana tidak sesuai dengan idiologi NW. Sehingga, masing-masing kampus juga membentuk sebuah organisasi mahasiswa HIMMAH NW (Himpunan Mahasiswa Nahdlatul Wathan) yang bukan kontrol dari struktur kampus, tetapi langsung dari struktur yayasan. Dua organisasi tersebut memiliki nama yang sama berhubungan organisasi tersebut memiliki kultur yang sama pula. Melihat budaya di wilayah Kabupaten Lombok Timur tentang Kehidupan masyarakat Islam Sasak di wilayah Kabupaten Lombok Timur, tergambar dalam bingkai yaitu agama, birokrasi dan budaya (adat istiadat).

Berbeda dengan budaya lokal, agama telah menempati posisi sentral dalam kehidupan masyarakat di pulau Lombok, khususnya masyarakat Islam Sasak di wilayah Lombok Timur yang terkonstruksi dari aliran-aliran keagamaan. Orang Sasak sebagai penduduk asli pulau Lombok, khususnya di Lombok Timur mayoritas beragama Islam. Lebih jelasnya pada catatan statistik, penduduk agama Islam selama tahun 2009 adalah sebanyak 1.095.487 jiwa atau sekitar 99,94 persen, agama Kristen sebanyak 137 orang, dan Hindu 539

orang

(http://lomboktimurkab.go.id).

Ketersediaan fasilitas pribadatan, Lombok Timur dikenal dengan sebutan seribu masjid, dimana pada tahun 2009 tercatat masjid sebanyak 1.184 . sedangkan untuk Gereja 1 unit dan Pura 1 unit (BPS, 2011, p. 275). Hal ini telah 
menyebabkan posisi "agama" berada dalam genggaman tangan kanan dan "budaya" berada dalam tangan kiri.

Agama dalam Kamus Besar Bahasa Indonesia (KBBI) adalah ajaran, sistem yang mengatur tata keimanan (kepercayaan) dan pribadatan kepada Tuhan Yang Mahakuasa serta tata kaidah yang berhubungan dengan pergaulan manusia dan manusia dan lingkungannya. Agama memberlakukan berbagai pranata dan norma serta menuntut agar para penganutnya berprilaku menurut pranata dan norma yang telah digariskan agama tersebut untuk membimbing mereka menuju keselamatan. Dalam dinamikanya, agama menjadi barang komuditas (konsumsi politik). Di dalam kehidupan masyarakat Islam Sasak di pulau Lombok, khususnya di wilayah Lombok Timur, agama sering dijadikan instrument politic yang pratama dan utama oleh golongan politisi, bahkan telah dijadikan jargon-jargon politik. Akan tetapi dalam kondisi tertentu dakwah agama dari seorang da'i kadangkadang larut dalam kepentingan politik dan terjadi posisi sebaliknya.

Ikatan Komunitas adat dan para pemimpin adat, menjadi hambatan utama para da'i untuk menerima dakwah mereka. Mereka lebih patuh pada adat dan menerima da'wah hanya dalam pengertian sempit. Adat masih sangat menonjol dan berpengaruh dalam kehidupan masyarakat Islam Sasak. Dalam kondisi dan situasi tertentu, kadang-kadang ditempatkan adat di tangan kanan dan di tangan kiri adalah agama.

Birokrasi menjadi perhatian penting bagi masyarakat Lombok Timur. Pelaksanaan adat dan agama di Lombok Timur dikelola dalam kerangka sistem birokrasi. Bagian penting dari sistem birokrasi modern adalah kepemimpinan formal pada tingkat regional mulai dari provinsi hingga desa. Jika sumber dari otoritas tradisional adalah nilai-nilai kebudayaan lokal, maka kekuasaan dari otoritas birokrasi tergantung pada kesetiaan orang birokrat terhadap atasan pemerintahan mereka.

Pemimpin Islam di Lombok Timur dikenal dengan nama Tuan Guru sejenis kyai di Jawa. Keberadaan tuan guru menjadi fenomenal, bahkan kekuasaannya secara informal melebihi pejabat pemerintah. Hal ini berefek berbeda dalam mensikapi tradisi-tradisi lokal, secara formal keIslaman tuan guru mengharamkan tari jangger, gendang beleq, cilokaq, perisean apalagi minum brem.

Kedudukan Kepala Desa di wilayah Kabupaten Lombok Timur sangat 
unik dan ambigu. Dari hasil observasi kepala desa memegang kendali atas wilayah desa. Posisi kepala desa juga bertindak sebagai ketua adat desa yang harus memelihara adat di desanya. Dengan demikian pemerintah sebagai elit politik lokalmerangkul adat sebagain instrumen pendekatan terhadap pendidikan politik.

Dalam realitasnya bahwa peranan kepala desa di wilayah Kabupaten Lombok Timur banyak memainkan peranan sebagai seseorang birokrat dan pejabat pemerintahan desa yang sebagian besar posisi tradisional didominasi oleh tokoh-tokoh setempat. Tokoh-tokoh tersebut bertindak sebagai perpanjangan tangan pemerintah yang membantu pelaksanaan program-program baru pemerintah di desanya yang dibantu oleh klian dusun yang mengembangkan program pemerintah di tingkat dusun dan mencatat demograsi dusunnya dan menjaga keamanan dusun yang dilaporkan ke kepala desa.

Hal tersebut dimaknai bahwa posisi Klian Dusun menangani berbagai masalah adat di tingkat dusun. Salah satunya yang dapat dilihat adalah "perkawinan". "Klian dusun" bertindak memberitahukan orang tua gadis setelah anak gadis mereka dilarikan dalam bahasa sasak adalah selabar (Profil
Lombok Timur, 2002, p. 28). Di samping itu, "klian dusun" memiliki fungsi sebagai mendamaikan keluarga penganten pria dan wanita dalam sebuah pertemuan untuk membicarakan denda merariq (kawin lari). Klian Dusun berfungsi juga sebagai penyilak atas nama pihak penyelenggara upacara adat perkawinan dan mengumumkan tujuan penyelenggaraan ritual tertentu kepada para tamu adat.

Hubungan Kepala desa (sebagai pejabat birokrat) dengan da'i terjadi hubungan sinergis, sehingga kepala desa mengangkat para da'i menjadi karakterdes (kader teritorial desa) dalam rangka membantu kemenangan politik tertentu dalam pemilihan umum. Sehinggan peran elit politik lokaldalam menyelenggarakan pendidikan politik tidak terlepas peran dari tuanguru atau kiai yang memiliki figur sentral pada masyarakat sasak di Lombok Timur.

Lombok Timur sebagai "seribu masjid". Hal ini terlihat paling dominan dalam pembangunan karakter masyarakat Islam Sasak di Lombok Timur disamping tradisi adalah unsur agama Islam. Dua iqon budaya ini telah mewarnai dalam tradisi kehidupan masyarakat Sasak.

Iqon tersebut dapat dilihat dari tradisi yaitu prisean yang merupakan 
bentuk kesenian bela diri dengan menggunakan sebilah rotan dengan lapisan aspal dan pecahan kaca yang dihaluskan berfungsi sebagai alat untuk memukul. Sedangkan prisainya dinamakan dalam bahasa sasak adalan ende terbuat dari kulit lembu atau kerbau. Kesenian ini tidak lepas dengan iringan musik yang membangkitkan semangat untuk berperang (Profil Lombok Timur, 2002, p, 24). Di sisi lain, budaya Islam disebut "santri". Iqon budaya ini kini menjadi energi kekuatan masyarakat Islam Sasak dan peran elit politik lokal menjadikan iqon ini menjadi pendekatan atau strategi dalam mempengaruhi yang tidak lepas dalam kontek kajian adalah pendidikan politik mahasiswa yang menjadi fokus kajian ini.

Pertama, Pada lingkungan Partai Keadilan Sejahtera, setiap anggota partai diharapkan mampu menjadi pekerja ekonomi yang cukup berkerja selama satu tahun. Melalui pelatihan kaderasisi, calon anggota diberikan pembelajaran tentang manajemen ekonomi dengan tujuan membentuk karakter kemandirian terhadap kader.

Kedua, berbeda dengan hasil yang dilaksanakan Partai Golkar yaitu, menghasilkan kader yang memiliki loyalitas dan dedikasi terhadap partai. Hal ini dikarenakan kurikulum yang diterapkan oleh Partai Golkar tidak ditemukan materi yang menekankan pada manajemen ekonomi. Sehingga kader Partai Golkar di Lombok Timur memiliki loyalitas terhadap partai saja.

Tabel 1. Tipe Partai Politik

\begin{tabular}{|c|c|c|}
\hline Aspek & PKS & Golkar \\
\hline $\begin{array}{c}\text { Kultura } \\
\text { l }\end{array}$ & Islam & Nasionalis \\
\hline $\begin{array}{l}\text { Sumber } \\
\text { dukunga } \\
\text { n }\end{array}$ & $\begin{array}{l}\text { Dukungan } \\
\text { datang dari } \\
\text { kelompok } \\
\text { yang } \\
\text { memiliki } \\
\text { karakteristik } \\
\text { islami }\end{array}$ & $\begin{array}{l}\text { Dukungan } \\
\text { bersifat } \\
\text { umum } \\
\text { dengan } \\
\text { mementingk } \\
\text { an nilai } \\
\text { pluralisme }\end{array}$ \\
\hline $\begin{array}{l}\text { Organis } \\
\text { asi } \\
\text { internal }\end{array}$ & $\begin{array}{l}\text { Merekrut } \\
\text { anggota atas } \\
\text { dasar agama }\end{array}$ & $\begin{array}{l}\text { Menghormat } \\
\text { i pluraslisme }\end{array}$ \\
\hline $\begin{array}{l}\text { Tindaka } \\
\mathrm{n} \text { dan } \\
\text { fungsi }\end{array}$ & $\begin{array}{l}\text { Tersepesialis } \\
\text { asi dengan } \\
\text { menekankan } \\
\text { keterwakilan }\end{array}$ & $\begin{array}{l}\text { Tersepesialis } \\
\text { asi dengan } \\
\text { menekankan } \\
\text { keterwakilan }\end{array}$ \\
\hline
\end{tabular}

Ketiga, di lingkungan pemerintah yaitu Dinas Badan Kesatuan Bangsa dan Politik yang memiliki tanggungjawab dari pemerintah daerah untuk melakukan sosialisasi politik. Hasil dari pelaksanaan pendidikan politik yang dilakukan institusi ini adalah capaian hasil masih mencapai 55\% dari 20 Kecamatan yang di Lombok Timur dan tingkat ketercapaian ini sudah bagus. Seperti yang diungkapkan sebelumnya, pemberian pendidikan politik yang dilaksanakan institusi ini berupa penyuluhan dan penyampain pesan dari pemerintah. 
Keempat,

organisasi

kemahasiswaa internal kampus seperti Himpunan Mahasiswa Islam yang bercabang di Kabupaten Lombok Timur, dan Himpunan Mahasiswa Nahdlatul Wathan. Dari hasil pelaksanaan pendidikan di Himpuan Mahasiswa Islam (HMI) yang bercabang di Lombok Timur terlihat mahasiswa dalam pergerakan ini memiliki pemikiran kritis terhadap analisis masalah. Terlihat pada aksi demonstrasi yang dilakukan pergerakan mahasiswa.

\section{Berbeda dengan Himpunan} Mahasiswa Nahdlatul Wathan (HIMMAH NW) yang menegaskan terhadap anggota tidak melaksanakan tindakan demonstrasi. Mahasiswa di Himmah tidak ditagaskan untuk mengambil langkah dengan cara demonstrasi, tetapi kita tegaskan untuk ikut mengambil tindakan dalam formulasi kebijakan.

Kelima, lembaga perguruan tinggi. Melihat kondisi pada lembaga perguruan tinggi di Lombok Timur yaitu STMIK Anjani membatasi akan adanya organisasi internal mahasiswa dilingkungan kampus. Keberadaan organisasi internal mahasiswa cenderung memprovokasi mahasiswa untuk menentang kebijakan kampus. Oleh sebab itu, kampus STMIK Anjani memiliki kultur Ke-NW-an hanya memberikan HIMMAH NW untuk melaksanakan kaderisasi di lingkungan perguruan tinggi.

Keenam, tokoh informal yang memiliki peran sebagai pendukung dalam kegiatan pendidikan politik untuk mahasiswa. Posisi tokoh informal di Kabupaten Lombok Timur sebagai mitra elit politik lokal dalam pembinaan pemuda dan khususnya mahasiswa di Kabupaten Lombok Timur. Angakatan muda khusunya mahasiswa belum menunjukkan kemandirian karena disebabkan oleh figur-figur pemberat yang menjadi figur sentral. Ketidak mandirian pemuda dan mahasiswa dilihat dari mahasiswa cenderung mengikuti arahan dari figur pemberat. Hal tersebut dinilai bahwa mahasiswa hanya sebagai pengikut dari lingkaran perintah dari seseorang yang ditokohkan, dan tidak memperlihatkan kemandirian berupa berpendapat atau mengajukan sebuah saran atau pendapat terhadap kebijakan dan kebijaksanaan bagi masyarakat.

Pembahasan dalam kajian ini melihat peran dari Partai Keadilan Sejahtera, dengan malalui pelatihan untuk para anggota dan khususnya calon anggota baru, dapat melalui Training Orientasi Partai (TOP). TOP dilaksanakan dua kali, dan untuk TOP yang pertama ditujukan kepada calon anggota baru sebagai pendidikan dasar. Sehubungan 
dengan hal tersebut, partai ini memiliki kurikulum berdasarkan perjenjangan. Seperti TOP pertama diikuti oleh para calon kader (pemula), dan ini merupakan pintu awal dari pendidikan politik di lingkungan Partai Keadilan Sejahtera. Selanjutnya dilaksanakan malalui Training Orientasi Partai (TOP) kedua. Tahap kedua ini memberikan pendidikan kepada pemula yang sudah terdaftar dan menjadi kader Partai Keadilan Sejahtera yang sudah sah.

Berbeda yang dilaksanakan Partai Golkar yang pendidikan politiknya dilakukan dengan bentuk pelatihan dengan metode diskusi. Akan tetapi, partai ini untuk merangkul mahasiswa sudah mempersiapkan bidang pemuda. Bagi Partai Golkar dari elemen apapun mahasiswa tersebut, Golkar sudah menyiapkan bidang sebagai tempat menyentuh atau melibatkan diri dalam lingkungan Partai Golkar. Hal yang sama juga dimiliki oleh PKS seperti Gerakan Muda Profesional (GEMPRO) yang ditujukan bagi para pemuda.

Perbedaan dari segi kultur juga yang menjadi alasan mahasiswa untuk mengikuti atau ikut bergabung dalam partai politik, dimana PKS memiliki kultur berwajah Islam sehingga mahasiswa yang mengikuti pelatihan di PKS merupakan mahasiswa yang terorientasi pada
Lembaga Dakwah Kampus sebagai UKM di lingkungan kampus. Sedangkan di Golkar yang dikenal dengan partai yang memiliki karakteristik nasioanal menyentuh mahasiswa dengan cara yang fleksibel atau tidak melihat dari warna yang dimiliki mahasiswa. Hal ini menjadi strategi yang diterapkan pada masingmasing partai politik dengan mempertimbangkan pengalaman yang dimiliki mahasiswa dari pendidikan politik sudah diperoleh di lingkungan kampus yang dibungkus dalam satuan kurikulum dan kegiatan-kegiatan ekstra seperti kegiatan berorganisasi kemahasiswaan lainnya baik itu dilaksankan secara formal dan nonformal.

Selain hal tersebut di atas, untuk beberapa mahasiswa di masing-masing kampus, adanya partisipasi mahasiswa yang cukup tinggi, mahasiswa yang memiliki semangat untuk mengikuti kegiatan keorganisasian di kampus. Oleh sebab itu, keaktifan mahasiswa dalam berorganisasi menjadi ukuran pelaksanaan pendidikan politik mahasiswa di kampus seperti pelatihan kepemimpinan.

Dukungan kebijakan pendidikan politik secara nasional ada pada UndangUndang Negara Republik Indonesia 1945 pasal 6A ayat (2) dan pasal 22E ayat (4) terkandung beban sebenarnya ada pada 
Negara yang memiliki tugas aktif untuk menciptakan sistem politik yang memampukan rakyat untuk aktif dan bebas dalam partisipasi hubungan publik dan politik. Namun demikian, di sisi lain partai politik juga memiliki peran yang penting dalam proses pengkondisian sistem politik karena partai merupakan sarana utama dalam struktur demokrasi partisipatif.

Upaya elit politik lokal dalam memberikan pendidikan politik tertuang dalam sebuah kebijakan. Secara normatif, fungsi Partai Politik dalam pelaksanaan pendidikan politik sudah di atur oleh Undang-Undang Nomor 2 Tahun 2011 pada pasal 3 ayat 4 (a) dan (b) yang mengatur pendidikan politik berupa dukungan bantuan anggara pelaksanaan di tingkat nasional dan daerah. Bukan hanya itu, dari hasil wawancara peneliti menemukan Pemerintah Kabupaten Lombok Timur juga mendukung pelaksanaan pendidikan politik, di karenakan pendidikan politik untuk masyarakat dan angkatan muda juga merupakan misi dari Kabupaten Lombok Timur. Kebijakan pendidikan politik yang akan dilaksanakan termaktub dalam Pasal 22 Ayat 1 dalam Peraturan Daerah Nomor 4 Tahun 2008 tentang organisasi dan tata kerja perangkat daerah. Hal tersebut secara langsung menjadi tugas dari institusi yang ada dilingkungan Pemerintah daerah Kabupaten Lombok Timur yaitu Dinas Bangkesbangpoldagri. Pemerintah dengan Partai Politik melaksanakan berupa penyuluhan dan penyampain pesan-pesan dari pemerintah Kabupaten Lombok Timur. Sedangkan, dari partai politik proses pelaksaanaanya tidak terlepas dari indoktrinasi partai politik berupa pelatihan untuk kader partai. Mengutip pendapat dari Zamroni (2001, p. 22) dalam bukunya "pendidikan untuk demokrasi" prinsip indoktrinasi harus diminimalkan karena tidak mungkin dihilangkan dan diganti dengan prinsip dialog. Aktivitas berbau paksaan harus diubah menjadi aktivitas dengan nuansa kesadaran.

Elit politik lokal di Kabupaten Lombok Timur ditemukan belum memberikan pendidikan politik untuk angkatan muda seperti mahasiswa pada umumnya. Kegiatan yang dilakukan masih terfokus pada konsolidasi konstituen dan marak dilakukan pada saat kampanye. Kampanye politik diartikan sama dengan pendidikan politik, dan pada pelaksanaannya dalam porsi minim tidak terpola yang terbatas pada konstituen. Hal ini dapat diartikan adalah bersifat indoktrinasi, karena dalam proses pelaksanaan terfokus pada 
tujuan untuk menjaring pendukung sebanyak-banyaknya.

Keterlibatan perguruan tinggi di Kabupaten Lombok Timur diawali dengan pimpinan yayasan, sebagaimana perguruan tinggi swasta bernaung dibawah struktur yayasan. Pimpinan yayasan adalah bagian dari partai politik. Hal ini dapat disimpulkan karena pimpinan yayasan pada Sekolah Tinggi Keguruan dan Ilmu Pendidikan (STKIP) Hamzanwadi adalah salah satu aktor politik dan sekarang memiliki jabatan sebagai Gubernur Nusa Tenggara Barat. Hal yang sama pada perguruan tinggi STMIK Syekh Zaenuddin yang menggiring perguruan tinggi ikut dalam politik praktis. Pada perguruan tinggi ini secara terang-terangan menginstruksikan warga perguruan tinggi untuk mendukung salah satu calon yang diusung oleh pimpinan yayasan dan memberikan konsekuensi yang tegas terhadap warga perguruan tinggi yang tidak mendukung. Secara langsung, dapat mempengaruhi mahasiswa yang untuk terlibat politik secara praktis. Keterlibatan mahasiswa tersebut, dapat dilihat dari keikutsertaan mahasiswa dalam proses kampanye terbuka elit politik lokal.

Adapun hal yang lain dapat dilihat dari keterlibatan elit politik lokaldalam lingkungan kampus yang diwarnai dengan proses pembekalan dengan teknik pembelajaran untuk mempengaruhi suara masyarakat malalui program kampus seperti Kuliah Kerja Nyata (KKN). Selain malaksanakan pengabdian terhadap masyarakat, mahasiswa ditemukan diluar jam kegiatan malakukan penyebaran atribut kampanye dari salah satu calon yang menjadi afiliasi dukunga dari pihaya yayasan. Disamping itu, memadukankan kegiatan yang terjadwal dalam menjalankan proses KKN secara tidak langsung mahasiswa membangun komunikasi secara politik terhadap masyarakat dilokasi KKN. Hasil observasi juga menunjukkan adanya selebaran kampaye politik di madding kampus dengan seruan supaya memilih calon yang didukung oleh yayasan.

Sebagaimana elit politik lokal yang memiliki peran dalam pendidikan politik mahasiswa, tidak terlepas juga peran elit masyarakat seperti tokoh agama, elit kemasyarakatan, kepemudaan, dan lain sebagainya yang berperan mewarnai kegiatan pendidikan politik. Dari hasil penelitian, Kabupaten Lombok Timur memiliki masyarakat yang bermayoritas beragama Islam. Agama di daerah ini berada pada posisi tangan kanan, jadi posisi tuanguru atau kiai yang merupakan 
kendali di tengah-tengah masyarakat. Sehingga, elit politik lokalsetempat membangun hubungan baik dengan para tokoh informal dalam upaya menjalankan misi partai, misi daerah, dan sebagai instrumen penjaring massa melalui figur sentral seorang tokoh di Kabupaten Lombok Timur.

Posisi tokoh informal yang langsung berada di tengah-tengah masyarakat dan sebagai figur sentral dalam masyarakat menjadi strategi elit politik lokaldalam penyampai misi dan kepentingan. Melalui ceramah keagamaan di masjid dan sekolah sering dilakukan. Karena tokoh informal di Lombok Timur sebagian besar menjadi pengasuh lembaga pendidikan. Atau tidak, tokoh informal memiliki pengaruh dalam lembaga pendidikan seperti pondok pesantren. Peneliti menemukan, kampanye politik di lembaga pendidikan sering dilakukan dengan melibatkan mahasiswa, masyarakat sebagai penggerak. Akan tetapi sebagian mahasiswa yang cenderung melibatkan diri pada sebuah orgaanisasi kemahasiswaan yang tidak memiliki afiliasi terhadap persoalan politik, membatasi diri untuk tidak terlibat jauh. Mahasiswa yang tergolong organisator ini lebih menekankan aktivitas mereka sebagai pengontrol dari kebijakan pemerintah dan terlibat dalam bangunan aksi demonstrasi. Berbanding terbalik dengan mahasiswa orientasi politik melihat pada figur ketokohan dan cenderung mahasiswa seperti ini ada pada kalangan mahasiswa "songkok puteq" dengan ciri khasnya "kitab kuning di dada ku".

Peneliti menemukan pada dua Perguruan Tinggi di Kabupaten Lombok Timur yang merupakan tempat bagi mahasiswa untuk mengenyam sebuah pendidikan dan pemberdayaan pada bidang politik. Melalui kurikulum yang tertuang dalam pelajaran atau mata kuliah pendidikan kewarganegaraan, mahasiswa secara pendidikan formal langsung mendapatkan pendidikan politik. Untuk pendidikan nonformal, mahasiswa dapat mengikuti kegiatan ekstra organisasi di kampus.

Terkait dengan pendidikan formal di internal 2 (dua) perguruan tinggi di Lombok Timur, secara struktural berada di bawah payung yayasan. Pendidikan politik yang ditemukan masih terorientasi pada tindakan indoktrinasi. Hal ini tidak terlepas dari afiliasi organisasi terhadap partai politik, dan landasan organisasi. Pembelajaran tentang landasan organisasi atau Ke-NWan dalam satuan kurikulum lokal yang dikembangkan oleh lembaga pendidikan 
dari tingkat TK sampai dengan perguruan tinggi. Ini bertujuan untuk menghasilkan kader yang setia terhadap perjuangan TGKH. Hamzanwadi sebagai pioner pendiri organisasi NW yang pada saat ini besar di NTB berpusat di Kabupaten Lombok Timur dengan menerapkan doktrin sami'na wa ato'na yang terorientasi pada seruan mendengar, mentaati, dan mengikuti.

Sedangkan pendidikan non formal, sebagian mahasiswa berminat untuk bergabung dalam organisasi kemahasiswa luar dari kampus seperti HMI (Himpunan Mahasiswa Islam), PMII (Pergerakan Mahasiswa Islam Indonesia), dan KAMMI (Kesatuan Aksi Mahasiswa Muslim Indonesia) yang bercabang di Kabupaten Lombok Timur. Dari lokasi penelitian menunjukkan keberadaan beberapa elemen mahasiswa tersebut menjadi lawan dari perguruan tinggi. Terlihat keberadaan mereka di dalam perguruan tinggi memunculkan aksi protes atau demonstrasi terhadap sistem perguruan tinggi. Sehingga, ini menjadi alasan organisasi membentuk sebuah gabungan mahasiswa yang berlandasan garis organisasi. Gabungan mahasiswa yang berada di bawah organisasi diberikan wewenang untuk berkembang di lingkungan kampus.

\section{SIMPULAN}

Posisi elit politik lokal di Kabupaten Lombok dalam memberikan pendidikan politik bagi mahasiswa diselenggarakan melalui lembagalembaga yang memiliki peran langsung dalam proses penyelenggaraan. Bukan hanya pada partai politik saja, tetapi pendidikan politik mahasiswa menjadi tanggung jawab lembaga-lembaga eksekutif dan legeslatif. Selama ini, partai politik hanya malaksanakan pengkaderan untuk konstituennya, yang dalam hal ini mereka sebut pendidikan politik. Pendekatan yang dilakukan untuk mahasiswa adalah melalui bidang kepemudaan yang berfungsi sebagai sayap partai (underbow) guna mendapatkan kader dari golongan mahasiswa yang berkecenderungan adalah Unit Kegiatan Mahasiswa (UKM) bidang Lembaga Dakwah Kampus (LDK) dan Himpunan Mahasiswa Nahdlatul Wathan (HIMMAH NW) baik keterlibatan secara langsung dan tidak langsung.

Lembaga Perguruan Tinggi di Kabupaten Lombok Timur secara umum berstatus sebagai Lembaga Perguruan Tinggi Swasta (PTS), yang tidak menutup kemungkinan memiliki komando di bawah struktur yayasan. Keterlibatan struktur yayasan dalam politik praktis membawa dampak pada lembaga pendidikan yang di kelola. Oleh Karena 
itu, lembaga pendidikan seperti Lembaga Perguruan Tinggi yang memiliki kelompok mahasiswa dan menurut usia mahasiswa notabenenya sudah mengantongi hak wajib pilih dalam proses demokrasi negara, yang secara langsung memberikan tekanan pada mahasiswa untuk mendukung afiliasi politik yayasan. Fakta dan fenomenanya terlihat, dalam kegiatan Kuliah Kerja Nyata (KKN) melalui pembekalan atau pengarahan untuk berkampanye politik pada masyarakat.

Sebagai saran dari peneliti yang mengacu pada hasil temuan di lapangan yaitu, Elit politik lokal di Kabupaten Lombok Timur perlu meningkatkan intensitas pendidikan politik tersebut dengan merumuskan pendidikan politik yang partisipatif khususnya untuk mahasiswa. Perlibata lembaga perguruan tinggi dalam mengintegrasikan pendidikan politik yang tidak terfokus pada proses indoktrinasi, yang sejatinya memperhatikan pengalamanpengalaman politik mahasiswa sebagai bagian pembentukan karakter mahasiswa sebagai bentuk nilai karakter menjadi warga negara yang baik.

\section{UCAPAN TERIMA KASIH}

Kami ucapkan terima kasih kepada para informan yang terlibat dalam penelitian ini, terutama para mahasiswa dari berbagai perguruan tinggi di Lombok Timur, sehingga penelitian ini dapat berjalan dengan baik. Selain itu kami ucapkan terima kasih kepada pihak-pihak yang turut membantu support dana sehingga penelitian ini bisa berjalan dengan lancar. Terima kasih kepada redaksi yang telah mempublikasikan artikel hasil penelitian ini.

\section{DAFTAR PUSTAKA}

Asry, Tahmidi., Gaffar Ismail., Safaruddin., et al. 2005. Profil Kabupaten Lombok timur. BIKD \& BAPPEDA Lombok Timur: Pemda Lombok Timur.

Badan Pusat Statistik Lombok Timur. 2012. Lombok Timur dalam Angka 2011 (No. 52030.1201). BPS Lombok Timur: Aksara Indah.

Kartono, Kartini. 2009. Pendidikan Politik: Sebagai Bagian Dari Pendidikan Orang Dewasa. Bandung: Mandar Maju.

Lombok Timur. 2011. Sejarah Berdirinya Lombok Timur. Diakses tanggal 5 November 2013 dari http://lomboktimurkab.go.id/?pil $\mathrm{ih}=$ pages\&mod=yes\&aksi=lihat\&i $\mathrm{d}=1$. 2013. Visi Dan Misi Pemerintah Kabupaten Lombok Timur. Diakses 
tanggal 5 November 2013 dari http://lomboktimurkab.go.id/?pil $\mathrm{ih}=$ pages\&mod=yes\&aksi=lihat\&i $d=93$

Massialas, Byron.G October 1970. The School In The Political Socialization Of Children And Youth. 144, NEA Stock Number 611-17780. Diakses pada tanggal 19 November 2013. dari http://www.ascd.org/ASCD/pdf/j ournals/ed_lead/el_197010_mass ialas.pdf.

Menkumham. 1999. Undang-Undang RI Nomor 39 Tahun 1999, tentang Hak Asasi Manusia.

Miles, B. Matthew., \& Michael Huberman. 1994. Qualitative Data Analysis:
Second Edition. London: SAGE Publications.

Molo, K. Yohanes. 8 April 2013. Golput, Potret Kegagalan Pendidikan Politik. Lombok Post, p. 2.

Nasution. 1988. Metode Penelitian Naturalistik Kualitatif. Bandung. Tarsito.

Petit, Phillip. 2002. Republicanism: A Theory of Freedom And Government. Oxford: Clarendon press.

Pramono, Agus. 2005. Elite Politik: Yang Loyo, Dan Harapan Masa Depan. Jakarta: Pustaka Sinar Harapan.

Zamroni. 2003. Pendidikan Untuk Demokrasi: Tantangan Menuju Civil Society. Yogyakarta: BIGRAF Publishing. 